\title{
Sensitizing EGFR Gene Mutation
}

National Cancer Institute

\section{Source}

National Cancer Institute. Sensitizing EGFR Gene Mutation. NCI Thesaurus. Code

C153232.

A change in the sequence of the EGFR gene that results in increased sensitivity to EGFR inhibitory agents. 